\title{
Enhancement of Power Generation in Microbial Fuel Cells through Supplementation of Platycodon grandiflorum in Doraji Roots
}

\section{Jung-In Park ${ }^{1,2}$, Hyunjin Kim¹, Dae Kyung Go³, Peter S. Park4, Sang Heon Lee ${ }^{1,5}$, Min Jung Koh², Jonathan Jo ${ }^{2}$, Donghoon Lee ${ }^{1}$, Seungshin Lee ${ }^{4}$, Paul S. Chung ${ }^{1,2}$}

${ }^{1}$ Fuzbien Technology Institute, Rockville, MD, USA

${ }^{2}$ Youth with Talents, Fairfax, VA, USA

${ }^{3}$ St. Johnsbuury Academy, Jeju, Korea

${ }^{4}$ Department of Biology, School of Arts and Sciences, Cornell University, Ithaca, NY, USA

${ }^{5}$ School of Arts and Sciences, Johns Hopkins, Baltimore, MD, USA

Email:paulschung08@gmail.com

How to cite this paper: Park, J.-I., Kim, H.-J., Go, D.K., Park, P.S., Lee, S.H., Koh, M.J., Jo, J., Lee, D.-H., Lee, S.S. and Chung, P.S. (2019) Enhancement of Power Generation in Microbial Fuel Cells through Supplementation of Platycodon grandiflorum in Doraji Roots. Journal of Sustainable Bioenergy Systems, 9, 169-178.

https://doi.org/10.4236/isbs.2019.94011

Received: September 19, 2019

Accepted: December 20, 2019

Published: December 23, 2019

Copyright $\odot 2019$ by author(s) and Scientific Research Publishing Inc. This work is licensed under the Creative Commons Attribution International License (CC BY 4.0).

http://creativecommons.org/licenses/by/4.0/

\section{(c) () Open Access}

\begin{abstract}
The current study reports the evidence of enhancement in power generation from cellulosic biomass in microbial fuel cell (MFC) systems by supplementing dried Doraji (Platycodon grandiflorum) roots powder. Mediator-less two chamber H-type MFCs were prepared using rumen fluid as anode inocula to convert finely ground pine tree (Avicel) at $2 \%(\mathrm{w} / \mathrm{v})$ to electricity. Dried Doraji roots were ground to pass $1 \mathrm{~mm}$ sieve and added to the anode of MFC at $0.1 \% \mathrm{w} / \mathrm{v}$ dosage for treatment. MFC power and current across an external resistor were measured daily for $10 \mathrm{~d}$. At the end of incubation on d10, collected gases were measured for total gas volume and analyzed for gas composition on gas chromatography. Supplementation of Doraji roots powder to MFC anode chamber increased power generation and $\mathrm{CO}_{2}$ production. Over the $10 \mathrm{~d}$ experimental period, power density normalized to anode surface area were between 17.0 and 37.7 with average of $32.5 \mathrm{~mW} / \mathrm{m}^{2}$ in Doraji MFCs, and between 16.8 and 19.8 with average of $18.2 \mathrm{~mW} / \mathrm{m}^{2}$ in control group. $\mathrm{CO}_{2}$ production increased and methane to $\mathrm{CO}_{2}$ ratio decreased in Doraji root treatment comparing to control group. These observations imply that Doraji root components would inhibit methanogenesis and alter microbial fermentation of cellulose compounds favorable to produce bioenergy efficiently in MFC.
\end{abstract}

\section{Keywords}

MFC, Platycodon grandiflorum 


\section{Introduction}

Fossil fuels have served as the main energy resources for industrialization and economic growth for the past century [1], and represented $80 \%$ of the global primary energy use [2], but the use of these also contributed $94 \%$ to $96 \%$ of greenhouse emission in the USA [3] including $\mathrm{CO}_{2}$, methane, $\mathrm{CO}$ and nitrous oxide $\left(\mathrm{N}_{2} \mathrm{O}\right)$, which cause global warming and pollution [4]. Thus, greater efforts are currently being undertaken to develop technologies generating clean and sustainable energy sources that would replace and/or displace fossil fuels [5].

Microbial fuel cell (MFC) is one of such technologies that directly convert biomass including organic waste to electricity [6]. MFC has shown tremendous electron donor versatility including simple substrates such as glucose, acetate, and lactate [7] [8] [9] complex substrates such as municipal and industrial wastewaters [10] [11] and cellulose [1] [12] [13] [14].

Cellulosic biomass is particularly attractive renewable resources because of its relatively low cost, plentiful supply [15] [16], and neutral carbon balance [17] and furthermore cellulose is a significant component in the annual production of 250 million tons municipal solid wastes and 40 billion cubic meters waste water [18]. To utilize cellulosic biomass in MFC, the anodic process requires cellulose degradation, but often the microorganisms that are electrochemically active did not show cellulolytic activity, thus, it requires products of cellulose fermentation as electron donors to generate electricity [19] [20]. Therefore, rumen fluid from cow [14] [21] or goat [22] had been studied for electricity generation from cellulose or cellulosic biomass because rumen microorganisms include both strict and facultative anaerobes, which effectively hydrolyze cellulose, and conserve energy via anaerobic respiration or fermentation [23]. However, one of major products from cellulose fermentation is acetic acid, and the acetate concentration and anaerobic condition influence the growth of methanogens which contribute significantly to limiting power generation in MFC. Methanogenesis diverts electron from the anode and methanogens act as substrate competitors to the exoelectrogens; acetoclastic methanogens compete for electron donors and hydrogenotrophic methanogens utilize the hydrogen produced in the reactor [24].

Supplementation of saponin or saponin rich plant materials has shown methanogenesis inhibitions [25] [26] [27] or proliferation of fiber degrading bacteria [28] in cultures of rumen microorganisms. Platycodon grandiflorum root (Korean name, "Doraji", Japanese name, "Kikyo", and Chinese name, "Jiegeng") has been reported to contain saponins [29] [30]. However, either Doraji root effects on methanogenesis in culture of microorganisms or saponin effects on anolyte fermentation characteristics has not been reported.

We hypothesized that supplementation of Doraji root in anolyte would inhibit methanogenesis and (or) proliferate cellulolytic microorganisms in anode chamber and subsequently ferment cellulosic biomass more efficiently and (or) enhance power generation in MFC. In the current study, MFCs were constructed 
with stained rumen fluid as anolyte and cellulose as electron donor, and effects of Doraji root supplementation on power generation and fermentation gas production were investigated.

\section{Materials \& Methods}

\subsection{Microorganisms and Culture Media}

For MFC anode compartment inoculum (anolyte), rumen fluid was collected from a dry dairy cow and while flushing of $\mathrm{CO}_{2}$ gas, filtered through 4 layers of cheesecloth to remove feed debris and transferred to an Erlenmeyer flask, then bubbled with $\mathrm{CO}_{2}$ gas for 10 min and closed with cotton ball and stored in an incubator at $39^{\circ} \mathrm{C}$ until inoculated to MFCs.

Culture medium containing $0.048 \% \mathrm{KH}_{2} \mathrm{PO}_{4}, 0.048 \% \mathrm{~K}_{2} \mathrm{HPO}_{4}, 0.048 \%\left(\mathrm{NH}_{4}\right)_{2} \mathrm{SO}_{4}$, $0.096 \% \mathrm{NaCl}, 0.5 \%$ Trypticase peptone, $5 \%$ yeast extract, $0.05 \%$ cysteine- $\mathrm{HCl}$, $0.013 \% \mathrm{CaCl}_{2} \cdot 2 \mathrm{H}_{2} \mathrm{O}, 0.02 \% \mathrm{MgSO}_{4} \cdot 7 \mathrm{H}_{2} \mathrm{O}, 0.4 \% \mathrm{Na}_{2} \mathrm{CO}_{3}, 0.1 \%$ sodium fumarate, and $1 \mathrm{ppm}$ of resazurin, was prepared anaerobically and autoclaved at $121^{\circ} \mathrm{C}$ for $30 \mathrm{~min}$ and stored at room temperature. Phosphate buffered saline pH7.4 (PBS) consisted of $137 \mathrm{mM} \mathrm{NaCl}, 2.7 \mathrm{mM} \mathrm{KCl}, 10 \mathrm{mM} \mathrm{Na}_{2} \mathrm{HPO}_{4}$, and $2 \mathrm{mM} \mathrm{KH}_{2} \mathrm{PO}_{4}$ and was autoclaved at $121^{\circ} \mathrm{C}$ for $30 \mathrm{~min}$ and stored at room temperature.

\subsection{Microbial Fuel Cells}

H-type MFCs consisted two $125 \mathrm{~mL}$-volume glass bottles joined at branched tube. Cation exchange membrane (CMI-7000S, Membranes International Inc., NJ) was placed and clamped between branched tube of anode and cathode compartments. Two gram of cellulose (Avicel PH-101, Sigma-Aldrich, MO) was weighed into anode chamber and $80 \mathrm{~mL}$ of culture medium, $20 \mathrm{~mL}$ strained rumen fluid were transferred, then suspended using a magnetic bar on agitator. Graphite plates $\left(12 \mathrm{~cm}^{2}\right)$ were used as electrodes for both anode and cathode. Electrode connected with copper wire fixed to butyl rubber stopper was placed in anode chamber. 100 $\mathrm{mL}$ of PBS was transferred to cathode chamber and electrode connected with copper wire was placed in the middle of cathode. Rubber stopper was capped on cathode but left open to air through tubing. Anode and cathode were connected externally through a copper wire with a resistor $(300 \mathrm{ohm})$. MFCs were placed in a water bath at $39^{\circ} \mathrm{C}$ for operation.

After $9 \mathrm{~d}$ of MFC pretrial operation, $100 \mathrm{mg}$ of dried Doraji root (C\&M Food, Seoul, Korea) ground to pass through $1 \mathrm{~mm}$ screen was added into anode chamber of treatment group. Two L-volume Mylar balloons were connected to each anode to collect biogas produced during experiment.

\subsection{Measurements and Calculation}

Using a digital multimeter, voltage across an external resistor (closed circuit voltage), open circuit voltage, and current were recorded daily for $10 \mathrm{~d}$. The power density normalized to electrode surface area was calculated using following equations. 


$$
P=\frac{I V}{A} \text { and } I=\frac{V}{R}
$$

where, $I(A)$ is the current, $V(V)$ is voltage, $R(\mathrm{ohm})$ is the external resistance, and $A\left(\mathrm{~m}^{2}\right)$ is the projected area of the anode.

The volume of biogases produced in anode collected in Mylar balloons were measured using a $250 \mathrm{~mL}$ glass syringe, and gas components were analyzed using an Agilent 6890 series gas chromatograph equipped with a thermal conductivity detector and a stainless steel packed column prepared with 60/80 Carboxen 1000 (12390-U Supelco, Sigma-Aldrich, MO).

\subsection{Statistical Analyses}

Effects of Doraji root addition to anode chamber of MFC on electricity generation, fermentation gas production and gas composition were analyzed using the one way ANOVA procedure of JPM 14.1.0 (SAS Institute Inc., NC). When the effect was significant $(\mathrm{P}<0.05)$, means between treatments were separated using Student's t-test $(\mathrm{P}<0.05)$. Means for operation time $(\mathrm{d})$ were separated using Tukey HDS where the operation time effects exist $(\mathrm{P}<0.05)$.

\section{Results and Discussion}

\subsection{Power Generation}

MFCs were stabilized and operational prior to treatment addition. Voltage across resistor, current density and power density were $96.4 \pm 4.87 \mathrm{mV}, 186.8 \pm 9.43$ $\mathrm{mA} / \mathrm{m}^{2}$ and $18.0 \pm 0.64 \mathrm{~mW} / \mathrm{m}^{2}$, respectively.

In control group, voltage across resistor (Table 1$)$ were steady $(\mathrm{P}=0.9766)$ with operation time and average was $96.8 \pm 5.22 \mathrm{mV}$ ranged from 93 to $101 \mathrm{mV}$, and end point potential (Table 2$)$ also did not change $(\mathrm{P}=0.9865)$ with operation time and average was $392 \pm 33.6 \mathrm{mV}$ ranged from 374 to $423 \mathrm{mV}$ during $10 \mathrm{~d}$ operation.

Voltage across resistor in MFCs received Doraji root powder increased ( $\mathrm{P}<$ $0.05)$ at $\mathrm{d} 2$ and maintained through $\mathrm{d} 10$ (Table 1$)$, but greater $(\mathrm{P}<0.05)$ end point potentials than $\mathrm{d} 0$ were observed only at $\mathrm{d} 2,5,7$ and 8 (Table 2). In comparison to control group, MFCs received Doraji root powder had greater ( $\mathrm{P}$ $<0.05$ ) voltage across resistor (Table 1 ) at $\mathrm{d} 2$ and thereafter through $10 \mathrm{~d}$ experimental period, and end point potential (Table 2) at d 5, 7, 8 and 10.

Power density (Table 3$)$ in control group did not change $(\mathrm{P}=0.9766)$ through operation time which reflects the steady cellulolysis and electricity generation during $10 \mathrm{~d}$ operation. Within Doraji received group, power density increased $(\mathrm{P}<0.05)$ at $\mathrm{d} 2$ from 17.0 to $35.6 \mathrm{~mW} / \mathrm{m}^{2}$ and these higher power density than $\mathrm{d} 0$ and $\mathrm{d} 1$ was maintained until the end of operation. Between treatments, from d 2 to $d 10$, power density in Doraji group were greater $(P<0.05)$ than in control group.

The enhanced power generation $(\mathrm{P}=0.0043)$ must be attributed to the action 
Table 1. Closed circuit voltage across $300 \mathrm{ohms}$ resistor measured from microbial fuel cells established with strained rumen fluid and $2 \%$ of cellulose with or without Doraji (Platycodon grandiflorum) roots powder addition.

\begin{tabular}{ccccc}
\hline & \multicolumn{4}{c}{ Voltage across resistor $(300 \mathrm{ohms}), \mathrm{mV}$} \\
\cline { 2 - 4 } Day & Control & Doraji & SEM $^{1}$ & $\mathrm{P}^{2}$ \\
\hline 0 & 97 & $94^{\mathrm{b}}$ & 4.0 & 0.6513 \\
1 & 95 & $94^{\mathrm{b}}$ & 4.0 & 0.8769 \\
2 & 97 & $136^{\mathrm{a}}$ & 3.6 & 0.0166 \\
3 & 93 & $139^{\mathrm{a}}$ & 3.6 & 0.0121 \\
4 & 100 & $137^{\mathrm{a}}$ & 3.9 & 0.0208 \\
5 & 95 & $135^{\mathrm{a}}$ & 0.7 & 0.0006 \\
6 & 95 & $136^{\mathrm{a}}$ & 5.4 & 0.0328 \\
7 & 98 & $135^{\mathrm{a}}$ & 4.5 & 0.0280 \\
8 & 101 & $133^{\mathrm{a}}$ & 0.8 & 0.0013 \\
9 & 96 & $140^{\mathrm{a}}$ & 4.4 & 0.0196 \\
10 & 100 & $135^{\mathrm{a}}$ & 2.2 & 0.0073 \\
$\mathrm{SEM}^{1}$ & 4.4 & 2.7 & & \\
$\mathrm{P}^{3}$ & 0.9766 & $<0.0001$ & & \\
\hline
\end{tabular}

${ }^{\mathrm{ab}}$ Means within a treatment with different superscripts differ, $\mathrm{P}<0.05 .{ }^{1}$ Standard error of means. ${ }^{2} \mathrm{P}$-value: probabilities that treatments effect is not significant within the day. ${ }^{3} P$-value: probabilities that day effect is not significant within the treatment.

Table 2. Terminal (open circuit) voltage measured from microbial fuel cells established with strained rumen fluid and $2 \%$ of cellulose with or without Doraji (Platycodon grandiflorum) roots powder addition.

\begin{tabular}{ccccc}
\hline \multirow{2}{*}{ Day } & \multicolumn{4}{c}{ Open circuit voltage, $\mathrm{mV}$} \\
\cline { 2 - 5 } & Control & Doraji & SEM $^{1}$ & $\mathrm{P}^{2}$ \\
\hline 0 & 385 & $356^{\mathrm{b}}$ & 29.4 & 0.5517 \\
1 & 406 & $412^{\mathrm{ab}}$ & 26.2 & 0.8861 \\
3 & 378 & $526^{\mathrm{a}}$ & 35.8 & 0.0997 \\
4 & 383 & $502^{\mathrm{ab}}$ & 22.8 & 0.0665 \\
5 & 381 & $459^{\mathrm{ab}}$ & 38.4 & 0.2895 \\
6 & 401 & $530^{\mathrm{a}}$ & 15.2 & 0.0267 \\
7 & 394 & $502^{\mathrm{ab}}$ & 33.8 & 0.1533 \\
8 & 395 & $522^{\mathrm{a}}$ & 20.2 & 0.0465 \\
9 & 400 & $509^{\mathrm{a}}$ & 15.8 & 0.0390 \\
10 & 374 & $464^{\mathrm{ab}}$ & 36.9 & 0.2271 \\
$\mathrm{SEM}^{1}$ & 423 & $466^{\mathrm{ab}}$ & 6.8 & 0.0466 \\
$\mathrm{P}^{3}$ & 29.9 & 24.7 & & \\
\hline
\end{tabular}

${ }^{\mathrm{ab} M e a n s}$ within a treatment with different superscripts differ, $\mathrm{P}<0.05$. ${ }^{1}$ Standard error of means. ${ }^{2} \mathrm{P}$-value: probabilities that treatments effect is not significant within the day. ${ }^{3} \mathrm{P}$-value: probabilities that day effect is not significant within the treatment. 
Table 3. Power density measured from microbial fuel cells established with strained rumen fluid and $2 \%$ of cellulose with or without Doraji (Platycodon grandiflorum) roots powder addition.

\begin{tabular}{ccccc}
\hline \multirow{2}{*}{ Day } & \multicolumn{4}{c}{ Open circuit voltage, $\mathrm{mV}$} \\
\cline { 2 - 5 } & Control & Doraji & SEM $^{1}$ & $\mathrm{P}^{2}$ \\
\hline 0 & 18.1 & $17.0^{\mathrm{b}}$ & 1.46 & 0.6624 \\
2 & 17.3 & $17.0^{\mathrm{b}}$ & 1.71 & 0.8719 \\
3 & 18.3 & $35.6^{\mathrm{a}}$ & 1.34 & 0.0118 \\
4 & 16.8 & $37.4^{\mathrm{a}}$ & 1.33 & 0.0082 \\
5 & 19.2 & $36.4^{\mathrm{a}}$ & 1.50 & 0.0150 \\
6 & 17.5 & $35.3^{\mathrm{a}}$ & 0.37 & 0.0009 \\
7 & 17.6 & $35.9^{\mathrm{a}}$ & 2.14 & 0.0263 \\
8 & 18.7 & $35.3^{\mathrm{a}}$ & 1.77 & 0.0220 \\
9 & 19.8 & $34.0^{\mathrm{a}}$ & 0.33 & 0.0011 \\
10 & 17.9 & $37.7^{\mathrm{a}}$ & 1.68 & 0.0141 \\
$\mathrm{SEM}^{1}$ & 19.2 & $35.3^{\mathrm{a}}$ & 1.12 & 0.0095 \\
$\mathrm{P}^{3}$ & 1.66 & 1.13 & & \\
\hline
\end{tabular}

${ }^{\mathrm{ab}}$ Means within a treatment with different superscripts differ, $\mathrm{P}<0.05$. ${ }^{1}$ Standard error of means. ${ }^{2} \mathrm{P}$-value: probabilities that treatments effect is not significant within the day. ${ }^{3} \mathrm{P}$-value: probabilities that day effect is not significant within the treatment.

of Doraji root powder supplementation that most likely causes favorable anode respiration by exoelectrogens by methanogenesis inhibitions [25] [26] [27] and (or) by cellulolysis extension with proliferation of fiber degrading bacteria [28] in MFCs constructed with rumen fluid as anolyte and cellulose as electron donor.

\subsection{Biogases Production}

Total gas productions in anode for 10d MFC operation were similar $(\mathrm{P}=0.7072)$ and the volumes were 328 and $335 \mathrm{~mL}$ in control and Doraji root treatment, respectively (Figure 1). Biomethane production were also similar $(\mathrm{P}=0.0248)$ and amounts were 220 and $197 \mathrm{~mL}$ in control and Doraji root treatment, respectively. However $\mathrm{CO}_{2}$ production was greater $(\mathrm{P}=0.0305)$ in Doraji root treatment $(138 \mathrm{~mL})$ than in control group $(108 \mathrm{~mL})$. The increase in $\mathrm{CO}_{2}$ and numerical difference in biomethane were clearly reflected in biomethane to $\mathrm{CO}_{2}$ ratio, and the ratio was less $(\mathrm{P}=0.0461)$ in Doraji root treatment $(1.44)$ than in control group (2.03).

Biogas is produced from biomass fermentation, and it was from cellulose in the current study. Because of the identical carbon balance between methane and $\mathrm{CO}_{2}$ and no difference in total gas production between treatment, the extend of cellulolysis might not influenced by treatment in the current study. Therefore, the enhanced power generation in Doraji rood added MFCs should be attributed to the methanogenesis reduction. Methanogenesis does not only divert electron from the anode but also reflects the competition of methanogens for substrates 


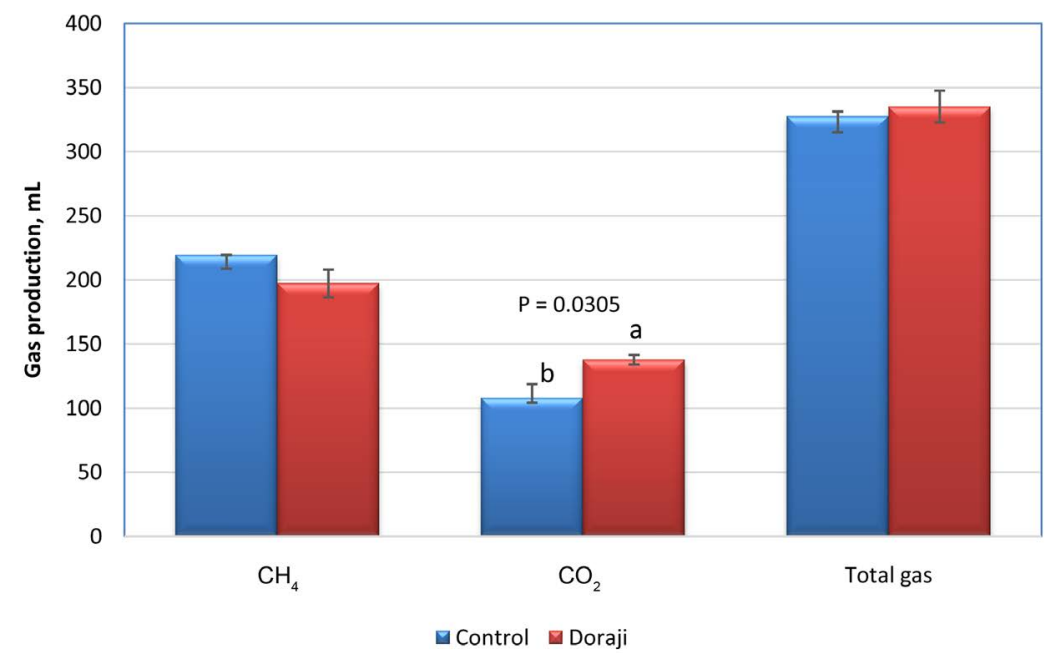

Figure 1. Accumulated gas production in the anode chamber of microbial fuel cells (MFCs). MFCs were built with rumen microorganisms and $2 \%$ of cellulose $\left(\right.$ Avicel $^{\circledast}$ ) with or without Doraji (Platycodon grandiflorum) roots powder addition Accumulated volume of gases were measured and analyzed for gas components on $\mathrm{d} 10$.

to exoelectrogens which transfer electrons to anode [24]. Aacetoclastic methanogens compete for electron donors $\left(\mathrm{CH}_{3} \mathrm{COO}^{-}+\mathrm{H}^{+} \rightarrow \mathrm{CH}_{4}+\mathrm{CO}_{2}\right)$ and hydrogenotrophic methanogens utilize the hydrogen produced in the reactor $\left(4 \mathrm{H}_{2}+\mathrm{CO}_{2} \rightarrow \mathrm{CH}_{4}+2 \mathrm{H}_{2} \mathrm{O}\right)$, and methanogenesis consumes exogenous energy (Kaur et al., 2014), and it is certainly not favorable for exoelectrogens establishment on anode which is critical in electricity generation in MFC.

\section{Conclusion}

Microbial Fuel Cell is one of the technologies that generate clean sustainable bioenergy from cellulosic biomass; however, methanogenesis remains as a major factor limiting MFC performance. In the current study, rumen microorganisms were employed as anolyte and cellulose served as electron donors, and Doraji (Platycodon grandiflorum) roots powder was tested at $0.1 \%$ of anolyte as methanogenesis inhibitor and cellulolytic microorganisms growth promoter. Cellulolysis did not change, however enhanced power generation and decreased methane to $\mathrm{CO}_{2}$ ratio were observed with Doraji roots powder addition to anode in MFC which were hypothesized on the basis of saponine effects on rumen microbial fermentation. Results from the current study imply that Doraji root addition would inhibit methanogenesis and enhance MFC efficiency in cellulosic electricity generation. Optimal dose and preparation methods of Doraji roots may be elucidated by further studies to maximize the methanogenesis inhibition and power generation in MFCs from cellulosic biomass.

\section{Acknowledgements}

The authors acknowledge the STEM Research Institute and Youth with Talents for sponsoring this research project (SRI-2018-5). 


\section{Conflicts of Interest}

The authors declare no conflicts of interest regarding the publication of this paper.

\section{References}

[1] Hassan, S.H., Kim, Y.S. and Oh, S.E. (2012) Power Generation from Cellulose Using Mixed and Pure Cultures of Cellulose-Degrading Bacteria in a Microbial Fuel Cell. Enzyme and Microbial Technology, 51, 269-273. https://doi.org/10.1016/j.enzmictec.2012.07.008

[2] Goldemberg, J. and Johansson, T.B. (2004) World Energy Assessment Overview: 2004 Update. United Nations Development Programme, New York.

[3] EPA (2016) Inventory of U.S. Greenhouse Gas Emissions and Sinks: 1990-2014. https://www.epa.gov/sites/production/files/2016-04/documents/us-ghg-inventory-2 016-main-text.pdf

[4] Saratale, G. and Oh, S. (2011) Production of Thermotolerant and Alkalotolerant Cellulolytic Enzymes by Isolated Nocardiopsis sp. KNU. Biodegradation, 22, 905-919. https://doi.org/10.1007/s10532-010-9450-0

[5] Levin, D.B., Islam, R., Cicek, N. and Sparling, R. (2006) Hydrogen Production by Clostridium Thermocellum 27405 from Cellulosic Biomass Substrates. International Journal of Hydrogen Energy, 31, 1496-1503.

https://doi.org/10.1016/j.ijhydene.2006.06.015

[6] Logan, B.E. and Regan, J.M. (2006) Microbial Fuel Cells-Challenges and Applications. Environmental Science \& Technology, 40, 5172-5180. https://doi.org/10.1021/es0627592

[7] Bond, D.R. and Lovley, D.R. (2003) Electricity Production by Geobacter sulfureducens Attached to Electrodes. Applied and Environmental Microbiology, 69, 1548-1555. https://doi.org/10.1128/AEM.69.3.1548-1555.2003

[8] Liu, H., Cheng, S. and Logan, B.E. (2005) Production of Electricity from Acetate or Butyrate Using a Single-Chamber Microbial Fuel Cell. Environmental Science \& Technology, 39, 658-662. https://doi.org/10.1021/es048927c

[9] Park, D.H. and Zeikus, J.G. (2002) Impact of Electrode Composition on Electricity Generation in a Single-Compartment Fuel Cell Using Shewanella putrefaciens. Applied Microbiology and Biotechnology, 59, 58-61. https://doi.org/10.1007/s00253-002-0972-1

[10] Min, B., Kim, J., Oh, S., Regan, J.M. and Logan, B.E. (2005) Electricity Generation from Swine Wastewater Using Microbial Fuel Cells. Water Research, 39, 4961-4968. https://doi.org/10.1016/j.watres.2005.09.039

[11] Aelterman, P., Rabaey, K., Clauwaert, P. and Verstraete, W. (2006) Microbial Fuel Cells for Wastewater Treatment. Water Science \& Technology, 54, 9-15. https://doi.org/10.2166/wst.2006.702

[12] Ishii, S., Suzuki, S., Norden-Krichmar, T.M., Nealson, K.H., Sekiguchi, Y. and Gorby, Y.A. (2012) Functionally Stable and Phylogenetically Diverse Microbial Enrichments from Microbial Fuel Cells during Wastewater Treatment. PLoS ONE, 7, e30495. https://doi.org/10.1371/journal.pone.0030495

[13] Rezaei, F., Richard, T.L., Brennan, R.A. and Logan, B.E. (2007) Substrate-Enhanced Microbial Fuel Cells for Improved Remote Power Generation from Sediment-Based Systems. Environmental Science and Technology, 41, 4053-4058. https://doi.org/10.1021/es070426e 
[14] Rismani-Yazdi, H., Christy, A.D., Dehority, B.A., Morrison, M., Yu, Z. and Tuovinen, O.H. (2007) Electricity Generation from Cellulose by Rumen Microorganisms in Microbial Fuel Cells. Biotechnology and Bioengineering, 97, 1398-1407. https://doi.org/10.1002/bit.21366

[15] Lynd, L.R., Weimer, P.J., van Zyl, W.H. and Pretorius, I.S. (2002) Microbial Cellulose Utilization: Fundamentals and Biotechnology. Microbiology and Molecular Biology Reviews, 66, 506-577. https://doi.org/10.1128/MMBR.66.3.506-577.2002

[16] Schwarz, W.H. (2001) The Cellulosome and Cellulose Degradation by Anaerobic Bacteria. Applied Microbiology and Biotechnology, 56, 634-649. https://doi.org/10.1007/s002530100710

[17] Niessen, J., Schröder, U., Harnisch, F. and Scholz, F. (2005) Gaining Electricity from in Situ Oxidation of Hydrogen Produced by Fermentative Cellulose Degradation. Letters in Applied Microbiology, 41, 286-290. https://doi.org/10.1111/j.1472-765X.2005.01742.x

[18] Perlack, R., Wright, L.L., Turhollow, A.F., Graham, A.F., Stokes, B.J. and Erbach, D.C. (2005) Biomass as Feedstock for a Bioenergy and Bioproducts Industry: The Technical Feasibility of a Billion-Ton Annual Supply. Oak Ridge National Laboratory, Oak Ridge. https://doi.org/10.2172/1216415

[19] Desvaux, M., Guedon, E. and Petitdemange, H. (2000) Cellulose Catabolism by Clostridium cellulolyticum Growing in Batch Culture on Defined Medium. Applied and Environmental Microbiology, 66, 2461-2470. https://doi.org/10.1128/AEM.66.6.2461-2470.2000

[20] Lovley, D.R. (2006) Bug Juice: Harvesting Electricity with Microorganisms. Nature Reviews Microbiology, 4, 497-508. https://doi.org/10.1038/nrmicro1442

[21] Wang, Z., Hong, Q., Shu, M., Chen, Y., Dong, L.X. and Ming, Y. (2014) Rumen Bacteria Convert Cellulose into Electricity in Two-Chamber Microbial Fuel Cell. Journal of Chemical and Pharmaceutical Research, 6, 727-732.

[22] Zang, G.-L., Sheng, G.-P., Tong, Z.-H., Liu, X.-W., Teng, S.-X. and Li, W.-W. (2010) Direct Electricity Recovery from Canna indica by an Air-Cathode Microbial Fuel Cell Inoculated with Rumen Microorganisms. Environmental Science \& Technology, 44, 2715-2720. https://doi.org/10.1021/es902956e

[23] Krause, D.O., Denman, S.E., Mackie, R.I. and Morrison, M. (2003) Opportunities to Improve Fiber Degradation in the Rumen: Microbiology, Ecology, and Genomics. FEMS Microbiology Reviews, 27, 663-693. https://doi.org/10.1016/S0168-6445(03)00072-X

[24] Rago, L., Guerrero, J., Baeza, J.A. and Guisasola, A. (2015) 2-Bromoethanesulfonate Degradation in Bioelectrochemical Systems. Bioelectrochemistry, 105, 44-49. https://doi.org/10.1016/j.bioelechem.2015.05.001

[25] Guo, Y.Q., Liu, J.-X., Lu, Y., Zhu, W.Y., Denman, S.E. and McSweeney, C.S. (2008) Effect of Tea Saponin on Methanogenesis, Microbial Community Structure and Expression of mcrA Gene, in Cultures of Rumen Microorganisms. Letters in Applied Microbiology, 47, 421-426. https://doi.org/10.1111/j.1472-765X.2008.02459.x

[26] Wang, C.J., Wang, S.P. and Zhou, H. (2009) Influences of Flavomycin, Ropadiar, and Saponin on Nutrient Digestibility, Rumen Fermentation, and Methane Emission from Sheep. Animal Feed Science and Technology, 148, 157-166. https://doi.org/10.1016/j.anifeedsci.2008.03.008

[27] Jadhay, R.V., Kannan, A., Bhar, R., Sharma, P.O., Gulati, A., Rajkumar, K., Mal, G., Singh, B. and Verma, M.R. (2018) Effect of Tea (Camellia sinensis) Seed Saponins on in Vitro Rumen Fermentation, Methane Production and True Digestibility at 
Different Forage to Concentrate Ratios. Journal of Applied Animal Research, 46, 118-124. https://doi.org/10.1080/09712119.2016.1270823

[28] Goel, G., Makkar, H.P.S. and Becker, K. (2008) Changes in Microbial Community Structure, Methanogenesis and Rumen Fermentation in Response to Saponin-Rich Fractions from Different Plant Materials. Journal of Applied Microbiology, 105, 770-777. https://doi.org/10.1111/j.1365-2672.2008.03818.x

[29] Lee, K.J., Choi, C.Y., Chung, Y.C., Kim, Y.S., Ryu, S.Y., Roh, S.H. and Jeong, H.G. (2004) Protective Effect of Saponins Derived from Roots of Platycodon grandiflorum on Tert-Butyl Hydroperoxide-Induced Oxidative Hepatotoxicity. Toxicology Letters, 147, 271-282. https://doi.org/10.1016/j.toxlet.2003.12.002

[30] Nyakudya, E., Jeong, J.H., Lee, N.K. and Jeong, Y.S. (2014) Platycosides from the Roots of Platycodon grandiflorum and Their Health Benefits. Preventive Nutrition and Food Science, 19, 59-68. https://doi.org/10.3746/pnf.2014.19.2.059 